\title{
Effectiveness of Bates Therapy (Ophthalmic Exercises) on Visual Acuity among Elderly People
}

\author{
Umamaheswari Ramesh ${ }^{1}$, Renuka K²
}

\begin{abstract}
Background: The eye is the window of the human body through which it feels its way and enjoys the beauty of the world, but as age rises, elderly people develop visual problems. Visual acuity is decreasing in most people older than 65 years. To improve the eyesight naturally, eye exercise is a set of massage that improves blood circulation and relaxes muscles in the ocular region.

Objectives: To assess the level of visual acuity among elderly people, to assess the effectiveness of Bates therapy on visual acuity among elderly people, and to find out the association of visual acuity among elderly people with selected demographic variables.

Methodology: Preexperimental—one-group pretest and posttest research design was adopted for the study. The population of the study was elderly people with decreased visual acuity. Thirty samples were selected by purposive sampling technique. The data were collected using a structured interview schedule and standardized visual acuity assessment scale (Snellen chart).

Results: The study result shows that in the right eye, the level of visual acuity among elderly people was as follows: In the pretest, 8 (26.6\%) had near-normal vision,19 (63.3\%) had moderate low vision, and $3(10 \%)$ had severe low vision. And in the posttest, 2 (6.6\%) had normal vision, 9 (30\%) had near-normal vision, and $19(63.3 \%)$ belong to moderate low vision. In the left eye, the level of visual acuity among elderly people was as follows: In the pretest, 6 (20\%) had near-normal vision, 22 had (73.35\%) moderate low vision, and $2(6.6 \%)$ had severe low vision. And in the posttest, $18(60 \%)$ had near-normal vision, $11(36.6 \%)$ had moderate low vision, and only one (3.3\%) belongs to severe low vision. The effectiveness of Bates therapy on the level of visual acuity among elderly people was assessed by using Wilcoxon signed-rank test. In the right eye, the pre- and posttest median scores were both three, respectively, and the Wilcoxon signed-ranks test value was 2.828 , and the obtained $p$ value was 0.005 . In the left eye, the pre- and posttest median scores were 3 and 2, respectively, and the Wilcoxon signed-rank test value was 3.357 , and the obtained $p$ value was 0.001 , which is highly statistically significant at $p<0.001 *$ level. It shows that the Bates therapy was effective for decreased visual acuity.

Conclusion: The study concludes that Bates therapy was effective in visual acuity among elderly people.

Keywords: Bates therapy, Elderly people, Visual acuity.

Pondicherry Journal of Nursing (2021): 10.5005/jp-journals-10084-13110
\end{abstract}

\section{INTRODUCTION}

The eye is the window through which the human body perceives and appreciates the beauty of the universe. However, as people age, they develop visual difficulties that manifest as symptoms such as visual defect, blurred vision, short sight, and foresight, among others, which obscure the beauty of eyesight. ${ }^{1}$ The majority of adults over the age of 65 have diminished visual acuity. ${ }^{2}$ Eye exercises might help improve the vision naturally. Eye exercise is a massage technique that improves blood circulation and relaxes muscles in the ocular region. ${ }^{3}$

The eye is the sensory organ responsible for gathering visual stimuli to assist people in communicating with the world around them. ${ }^{4}$ Aging is a journey or maturation that traditionally represents one of the constant and inexorable decreases that often reach a peak of efficiency in body function around the end of the second decade of life..$^{5}$ In addition, until very recently, the later years of life were conventionally seen as one of the withdrawal from the mainstream of life due to infirmity. ${ }^{6}$

In most adults over 65, their visual acuity has deteriorated. Age-related changes in the eye, nervous system, and supporting tissues have a variety of effects on visual function (appearance, cornea, ocular muscles, lens, iris, pupil, color vision, and tears). ${ }^{7}$ Retinal diseases are major among the older population. ${ }^{8}$

Three-fourths of the geriatric population in India is young old and elderly old. The average life expectancy at the beginning of 1900 was around 47 years, but by 2010, it was around 85 years or more. It was expected that the cumulative number of elderly
${ }^{1}$ Department of Obstetrics and Gynecology Nursing, Kasturba Gandhi Nursing College, Puducherry, India

${ }^{2}$ Department of Medical Surgical Nursing, Kasturba Gandhi Nursing College, Puducherry, India

Corresponding Author: Renuka K, Department of Medical Surgical Nursing, Kasturba Gandhi Nursing College, Puducherry, India, Phone: +91 9486537848, e-mail: renukagugan@yahoo.co.in

How to cite this article: Ramesh U, Renuka K. Effectiveness of Bates Therapy (Ophthalmic Exercises) on Visual Acuity among Elderly People. Pon J Nurs 2021;14(2):34-36.

Source of support: Nil

Conflict of interest: None

people worldwide would double from 62.3 million to 11.29 million between 1996 and 2016. ${ }^{9}$

According to the findings, the elderly who are institutionalized have a high rate of visual impairment. ${ }^{10} \mathrm{~A}$ study on effectiveness of Bates therapy in the treatment of visual problems in the elderly. For this study, a quantitative approach was used, as well as a preexperimental design with pre- and posttests. The study was conducted in 30 elderly people in Erode. Elderly people received Bates therapy two times a day for 30 days. Bates therapy was found to be effective in improving visual acuity in this study. ${ }^{11}$

Many older persons are affected by vision problems as they age. As a result, the necessity to publicize one of the most effective

(0) The Author(s). 2021 Open Access This article is distributed under the terms of the Creative Commons Attribution 4.0 International License (https:// creativecommons.org/licenses/by-nc/4.0/), which permits unrestricted use, distribution, and non-commercial reproduction in any medium, provided you give appropriate credit to the original author(s) and the source, provide a link to the Creative Commons license, and indicate if changes were made. The Creative Commons Public Domain Dedication waiver (http://creativecommons.org/publicdomain/zero/1.0/) applies to the data made available in this article, unless otherwise stated. 
methods of boosting visual acuity is understandable. ${ }^{12-14}$ Eye exercises allow the eye muscles to move freely. ${ }^{15}$ Eye exercises help to improve the vision naturally. ${ }^{16}$ Eye exercise is a massage technique that improves blood circulation and relaxes muscles in the ocular region. ${ }^{17}$ Eye exercises for vision improvement have been in use since the 1920s, when maverick ophthalmologist William Horatio Bates, MD, developed the Bates method. The Bates method has never been shown to improve eyesight in a substantial or long-term way. ${ }^{18}$

Bates therapy is useful to restore visual acuity. ${ }^{19}$

Bates therapy is a sequence of steps involving stretching, blinking, swinging, palming or cupping, and sunning. The Bates method's approach effectively reestablish the normal, natural relationship between the sight and the mind. ${ }^{20}$ So, the investigators had seen ophthalmic exercise, such as Bates therapy, as an effective method for improving visual acuity. As a result, the goal of this research is to see how successful is Bates therapy for improving visual acuity among the elderly.

\section{Statement of the Problem}

A study to assess the effectiveness of Bates therapy (ophthalmic exercises) on visual acuity among elderly people at Hospice Convent Home for Aged, Puducherry.

\section{Objectives of the Study}

- To assess the level of visual acuity among elderly people.

- To assess the effectiveness of Bates therapy on visual acuity among elderly people.

- To find out the association of visual acuity among elderly people with selected demographic variables.

\section{Hypothesis}

$\mathrm{H} 1$ : There is a significant difference in visual acuity among elderly people.

$\mathrm{H} 2$ : There is a significant association of visual acuity among elderly people with selected demographic variables.

\section{Materials and Methods}

Quantitative research approach preexperimental-one-group pretest and posttest research design study was adopted for this study. The study population was elderly people with decreased visual acuity at Hospice Convent Home for Aged, Puducherry. The study's sample size was 30 aged persons who were chosen using a purposive sampling technique. The visual acuity was assessed by a structured interview schedule and standardized visual acuity assessment scale (Snellen chart). The samples were informed about the nature and the purpose of the study by the researchers. After obtaining their informed consent, the old person's pretest score of visual acuity was measured. The Bates therapy was taught and demonstrated to the elderly after a pretest. Under the supervision of the investigator, the subject continued the Bates therapy (ophthalmic exercise) twice daily. The postscore of visual acuity was measured after 30 days. Finally, descriptive statistics (frequency and percentage) and inferential statistics (Wilcoxon signed-rank test and Chi-square test) were used to analyze the data. Discussions on the findings were presented based on the objectives of the study.

\section{Results}

Table 1 shows the level of visual acuity among elderly people in the right eye. In the pretest, 8 (26.6\%) had near-normal vision, 19 (63.3\%) had moderate low vision, and $3(10 \%)$ had severe low vision. And in the posttest, $2(6.6 \%)$ had normal vision, $9(30 \%)$ had near-normal vision, and $19(63.3 \%)$ belong to moderate low vision.

Table 2 shows the level of visual acuity among elderly people in the left eye. In the pretest, $6(20 \%)$ had near-normal vision, 22 had $(73.35 \%)$ moderate low vision, and $2(6.6 \%)$ had severe low vision. And in the posttest, $18(60 \%)$ had near-normal vision, 11 (36.6\%) had moderate low vision, and only one (3.3\%) belongs to severe low vision.

Table 3 shows the effectiveness of Bates therapy on the level of visual acuity among elderly people by using Wilcoxon signedrank test.

In the right eye, the pre- and posttest median scores were both 3 , respectively, and the Wilcoxon signed-rank test value was 2.828 , and the obtained $p$ value was 0.005 . In the left eye, the pre- and posttest median scores were 3 and 2, respectively, and the Wilcoxon signed-rank test value was 3.357, and the obtained $p$ value was 0.001 , which is highly statistically significant at $p<0.001^{*}$ level. It illustrates that Bates therapy was effective for decreased visual acuity. As a result, the stated hypothesis ( $\mathrm{H} 1)$ was accepted.

The association of levels of visual acuity with selected demographic variables of the elderly people was assessed. By using Chi-square test, it was evidenced that there was no significant association between age, higher educational status, marital status,

Table1: Percentage distribution of level of acuity on right eye among elderly

\begin{tabular}{lllllllll}
\hline & \multicolumn{8}{c}{ Level of visual acuity } \\
\cline { 2 - 9 } Observation & \multicolumn{2}{c}{$\begin{array}{c}\text { Normal } \\
\text { vision (\%) }\end{array}$} & \multicolumn{2}{c}{ Near-normal } \\
vision (\%) & $\begin{array}{l}\text { Moderate low } \\
\text { vision (\%) }\end{array}$ & \multicolumn{2}{l}{$\begin{array}{l}\text { Severe low } \\
\text { vision }\end{array}$} \\
\hline Right eye & $N$ & $(\%)$ & $N$ & $(\%)$ & $N$ & $(\%)$ & $N$ & $(\%)$ \\
Pretest & 0 & 0 & 8 & 26.6 & 19 & 63.3 & 3 & 10 \\
Posttest & 2 & 6.6 & 9 & 30 & 19 & 63.3 & 0 & 0 \\
\hline
\end{tabular}

Table 2: Percentage distribution of level of visual acuity on left eye among elderly

\begin{tabular}{lccllll}
\hline & \multicolumn{5}{c}{ Level of visual acuity } \\
\cline { 2 - 7 } Observation & \multicolumn{2}{c}{$\begin{array}{l}\text { Near-normal } \\
\text { vision }\end{array}$} & \multicolumn{2}{l}{$\begin{array}{l}\text { Moderate low } \\
\text { vision }\end{array}$} & \multicolumn{2}{l}{$\begin{array}{l}\text { Severe low } \\
\text { vision }\end{array}$} \\
\hline Left eye & $N$ & $(\%)$ & $N$ & $(\%)$ & $N$ & $(\%)$ \\
Pretest & 6 & 20 & 22 & 73.3 & 2 & 6.6 \\
Posttest & 18 & 60 & 11 & 36.6 & 1 & 3.3 \\
\hline
\end{tabular}

Table 3: Effectiveness of Bates therapy on the level of visual acuity among elderly people

\begin{tabular}{lllll}
\hline \multirow{2}{*}{ Visual acuity } & Test & $\begin{array}{l}\text { Median } \\
\text { score }\end{array}$ & $\begin{array}{l}\text { Wilcoxon } \\
\text { signed-ranktest }\end{array}$ & $p$-value \\
\hline \multirow{2}{*}{ Right eye } & Pretest & 3 & -2.828 & $0.005^{* *}$ \\
& Posttest & 3 & & \\
Left eye & Pretest & 3 & -3.357 & $0.001^{* * *}$ \\
& Posttest & 2 & & \\
\hline
\end{tabular}

${ }^{* * *} p<0.001$

${ }^{* *} p<0.01$ 
family history of visual problem, using smartphones, sex, previous occupational history, duration of using spectacles, history details of location, dietary pattern, associated disease condition, using spectacle while driving, taking any alternative therapies for visual problems, frequency of eye examination, and previous eye surgery. But, it was evidenced that there was a significant association with duration of the visual problem at $p$-value $<0.001$ level. As a result, the stated hypothesis $(\mathrm{H} 2)$ was accepted.

\section{CONCLUSION}

The main conclusion of the present study proved that Bates therapy (ophthalmic exercises) was effective on visual acuity among elderly people by usinga visual acuity assessment scale (Snellen chart). In the right eye, the pre- and posttest median scores were both 3, respectively, and the Wilcoxon signed-rank test value was 2.828 , and the obtained $p$ value was 0.005 . In the left eye, the pre- and posttest median scores were 3 and 2, respectively, and the Wilcoxon signed-rank test value was 3.357 , and the obtained $p$ value was 0.001 , which is highly statistically significant at $p<0.001 *$ level. It shows that the Bates therapy was effective for decreased visual acuity among elderly people. So, the Bates therapy was effective in visual acuity among elderly people.

\section{Recommendations}

- The study can be replicated with a larger sample for better generalization.

- More studies can be conducted to improve the visual acuity among elderly people, schoolchildren, computer users, etc., using different complementary and alternative modalities to establish a rightful place in ophthalmic care.

- A comparative study can be done to assess the effectiveness of Bates therapy versusacupressure on visual problems among elderly people.

- Studies can also be done to evaluate the effectiveness of other nursing interventions.

\section{References}

1. Sheelavathi N, Ganapathy N, Padmavathi P. Effectiveness of Bates therapy on visual problems among elderly people. Int J Adv Nurs Manage 2016;4(2):135-138. DOI: 10.5958/2454-2652.2016.00030.5.

2. Klein R, Klein BE, Lee KE. Changes in visual acuity in a population: the Beaver Dam Eye Study. Ophthalmology 1996;103(8):1169-1178. DOI: 10.1016/s0161-6420(96)30526-5.
3. Dharani A, Dhivyabharathi S, Divya K, et al. Ophthalmic exercises on Myopia. Asian J Nurs Educ Res 2019;9(1):43-50. DOI: 10.5958/23492996.2019.00008.

4. Velazquez R. Wearable assistive devices for the blind. In: Wearable and autonomous biomedical devices and systems for smart environment. Berlin: Springer, 2010, pp. 331-349.

5. Stuart-Hamilton I. The psychology of aging: an introduction. London: Jessica Kingsley Publishers, 2012.

6. Gill S. William Wordsworth: a life. Oxford: Oxford University Press, 2020.

7. Remington LA, Goodwin D. Clinical anatomy of the visual system E-Book. London: Elsevier Health Sciences, 2011.

8. Taylor HR, Keeffe JE. World blindness: a 21st century perspective. Br J Ophthalmol 2001;85(3):261-266. DOI: 10.1136/bjo.85.3.261.

9. Gott $\mathrm{M}$, Ingleton $\mathrm{C}$, editors. Living with aging and dying: palliative and end of life care for older people. Oxford: OUP, 2011.

10. Sainz-Gómez C, Fernández-Robredo P, Salinas-Alamán Á, et al. Prevalence and causes of bilateral blindness and visual impairment among institutionalized elderly people in Pamplona, Spain. Eur J Ophthalmol 2010;20(2):442-450. DOI: 10.1177/112067211002000228.

11. Thananki AB. Effectiveness of Bates therapy on visual problems among elderly residents at KK IIlam, home for aged, Erode (Doctoral dissertation, Dhanvantri College of Nursing, Namakkal).

12. Bouchard B, Imbeault F, Bouzouane A, et al. Developing serious games specifically adapted to people suffering from Alzheimer. In: International conference on serious games development and applications. Berlin: Springer, 2012, pp. 243-254.

13. Jessa Z, Evans B, Thomson D, et al. Vision screening of older people. Ophthalmic Physiol Opt 2007;27(6):527-546. DOI: 10.1111/j.14751313.2007.00525.x.

14. Hickson M. Malnutrition and aging. Postgrad Med J 2006;82(963): 2-8. DOI: $10.1136 / p g m j .2005 .037564$.

15. Franceschini N, Pichon JM, Blanes C. From insect vision to robot vision. Philos Trans R Soc Lond Ser B 1992;337(1281):283-294. DOI: 10.1098/ rstb.1992.0106.

16. Quackenbush TR. Relearning to see: improve your eyesight naturally. Berkeley: North Atlantic Books, 1999.

17. Richards KC. Effect of a back massage and relaxation intervention on sleep in critically ill patients. Am J Crit Care 1998;7(4):288. Available at: https://pubmed.ncbi.nlm.nih.gov/9656043/

18. Shinde MB, Anjum S. Effectiveness of slow back massage on quality of sleep among ICU patent's. IJSR 2014;3(3):292-298. Available at: https://www.researchgate.net/publication/266020716_ Effectiveness_of_Slow_Back_Massage_on_Quality_of_Sleep_ among_ICU_Patent's

19. Dalkara D, Goureau O, Marazova K, et al. Let there be light: gene and cell therapy for blindness. Hum Gene Ther 2016;27(2):134-147. DOI: 10.1089/hum.2015.147.

20. Sairam TV. The penguin dictionary of alternative medicine. London: Penguin, 2008. 